\title{
Spectrophotometric Assessment of Heme Oxygenase-1 Activity in Leishmania-infected Macrophages
}

Moumita Basu\#, Shriya Saha ${ }^{\#}$ and Anindita Ukil*

Department of Biochemistry, University of Calcutta, Kolkata, India

*For correspondence: $\underline{\text { u.anindita@gmail.com }}$

\#Contributed equally to this work

\begin{abstract}
[Abstract] Heme oxygenase-1 (HO-1) is a stress responsive enzyme that metabolizes heme and releases free iron, carbon monoxide (CO), and biliverdin (BV), which rapidly undergoes conversion to bilirubin (BL). Estimation of bilirubin is the basis of HO-1 assay. $\mathrm{HO}-1$ activity is widely employed to determine antioxidant response of cells under different physiological stress environment. Intra-macrophage infection often acts as such a stress inducer and measurement of HO-1 activity in infected cells indicates the ability of pathogens towards modulating oxidative response of host. The present protocol describes analysis of HO-1 activity in infected macrophages by spectrophotometric method, which is much less complex and therefore advantageous over other methods like high-performance liquid chromatography, radiochemical methods and detection of $\mathrm{CO}$ by gas chromatography. The main steps include: (1) Preparation of macrophage microsomal fraction containing HO-1 (2) Isolation of rat liver cytosolic fraction containing biliverdin reductase and (3) Assessment of heme oxygenase- 1 activity by spectrophotometric detection of bilirubin. This method provides a simple and sensitive approach to measure cellular antioxidant response under infected condition.
\end{abstract}

Keywords: Heme oxygenase-1, Macrophage, Leishmania, Spectrophotometry, Bilirubin, Hemin

[Background] Reactive oxygen species (ROS) is one of the major host defense arsenals against invading pathogens used by macrophages (Missall et al., 2004). On the other hand, intra-macrophage pathogens neutralize early oxidative burst for their successful persistence within macrophages (Paiva and Bozza, 2014). In response to such oxidative stress, organisms can deploy antioxidant enzymes of host cells such as superoxide dismutase (SOD), catalase (CAT) glutathione peroxidase (GPX), and heme oxygenase-1 (HO-1) to scavenge ROS (Kathirvel et al., 2010). Intracellular parasite Leishmania donovani could effectively exploit host antioxidant enzyme HO-1 for ROS neutralization (Saha et al., 2019). HO-1 is a potent anti-oxidant enzyme catalysing the oxidative cleavage of heme to generate carbon monoxide $(\mathrm{CO})$, ferrous iron $\left(\mathrm{Fe}^{2+}\right)$, and biliverdin $(\mathrm{BV})$. The biliverdin is further acted upon by another enzyme biliverdin reductase (BVR) to produce bilirubin (BL) (Tenhunen et al., 1969). There are several techniques to quantify the activity of $\mathrm{HO}-1$ based on detection of one of its ultimate reaction product bilirubin via high-performance liquid chromatography (Lincoln et al., 1988; Ryter et al., 1999), visible spectrophotometry (Schacter, 1978; Tenhunen et al., 1969) and radiochemical methods (Sierra and Nutter, 1992). Detection of CO by gas chromatography (Vreman and Stevenson, 1988) has also 
been used to assay HO-1 activity, but because of its complexity and subsequent product analysis steps the protocol is not variedly applicable. Now, biliverdin is the primary metabolite of the heme degradation by HO-1. However, it has poor spectral properties with an extinction coefficient $(\varepsilon)$ of $\sim 8$ to $10 \mathrm{mM}^{-1} \mathrm{~cm}^{-1}$ (Kutty and Maines, 1981). Thus, most common HO-1 activity assays rely on the reduction of biliverdin to bilirubin. Original spectrophotometric quantification of bilirubin for detection of HO-1 activity was outlined by Tenhunen et al. (1969). In the method, bilirubin formation was monitored spectrophotometrically by the increase in absorbance at $468 \mathrm{~nm}\left(\varepsilon_{468}=43.5 \mathrm{mM}^{-1} \mathrm{~cm}^{-1}\right)$, which is approximately 5 -fold higher than that of biliverdin. Modifications of this main spectrophotometric assay for assessment of HO-1 activity was carried out and HO-1 activity was determined by monitoring bilirubin formation using the difference in absorbance at 464 to $530 \mathrm{~nm}\left(\varepsilon_{464-530}=40 \mathrm{mM}^{-1} \mathrm{~cm}^{-1}\right)$ (Maines, 1996; Maines and Kappas, 1974).The current protocol (Figure 1) utilises the same principle but are performed with certain minor modifications to make it much more convenient.



Figure 1. Schematic representation of HO-1 activity assay

\section{Materials and Reagents}

1. Pipette tips (Tarsons, catalog numbers: $521020,521010,521000$ )

2. Tissue culture flasks, $50 \mathrm{ml}$ (Falcon, catalog number: 353108)

3. Cell scraper (Falcon, catalog number: 353086 )

4. Polypropelene conical tube, $50 \mathrm{ml}$ (Falcon, catalog number: 352070)

5. Microcentrifuge tubes, $1.5 \mathrm{ml}$ (Falcon, catalog number: 500010 )

6. $0.2 \mu \mathrm{m}$ syringe-driven filter unit (Millipore, catalog number: SLGP0033RS)

7. Quartz cuvette [10 mm, $1 \mathrm{ml}$ volume] (Optiglass, catalog number: MCQ-254)

8. Tissue papers

9. 26-gauge needle

10. $10 \mathrm{ml}$ syringe

11. Petri dish

12. RAW 264.7 cell (ATCC, catalog number: TIB-71) 
13. Murine bone marrow derived macrophages (BMDM) (isolated from BALB/c mice) (for details, see Recipes)

14. Leishmania donovani (MHOM/IN/1983/AG83)

15. DMEM medium (Gibco, catalog number: 11885-084)

16. M199 medium (Gibco, catalog number: 12340-030)

17. FCS (Gibco, catalog number: 10082-147)

18. Antibiotic solution, 100x (Himedia, catalog number: A001A)

19. Protein assay dye reagent concentrate (Bio-Rad, catalog number: 5000006)

20. 1 mM NAD(P)H (Santa Cruz, catalog number: sc-202725)

21. 2 mM glucose-6-phosphate (Santa Cruz, catalog number: sc-210728)

22. $1 \cup$ glucose-6-phosphate dehydrogenase (Sigma-Aldrich, catalog number: G-6378)

23. $25 \mu \mathrm{M}$ hemin (Sigma-Aldrich, catalog number: 51280)

24. Biliverdin hydrochloride (Sigma-Aldrich, catalog number: 30891)

25. $\mathrm{NaCl}(\mathrm{M} . \mathrm{W} .=58.44 \mathrm{~g} / \mathrm{mol})$

26. $\mathrm{Na}_{2} \mathrm{HPO}_{4}(\mathrm{M} . \mathrm{W} .=141.96 \mathrm{~g} / \mathrm{mol})$

27. $\mathrm{KCl}(\mathrm{M} . \mathrm{W} .=74.55 \mathrm{~g} / \mathrm{mol})$

28. $\mathrm{KH}_{2} \mathrm{PO}_{4}(\mathrm{M} . \mathrm{W} .=136.08 \mathrm{~g} / \mathrm{mol})$

29. $\mathrm{K}_{2} \mathrm{HPO}_{4}(\mathrm{M} . \mathrm{W} .=174.18 \mathrm{~g} / \mathrm{mol})$

30. $\mathrm{MgCl}_{2}(\mathrm{M} . \mathrm{W} .=95.211 \mathrm{~g} / \mathrm{mol})$

31. Sucrose (M.W. $=342.29 \mathrm{~g} / \mathrm{mol}$ )

32. Sodium citrate (M.W. $=258.06 \mathrm{~g} / \mathrm{mol}$ )

33. Glycerol

34. $70 \%$ ethanol

35. Phosphate buffer saline/buffer ( $\mathrm{pH} 7.4$ ) (for details, see Recipes)

36. $0.1 \mathrm{M}$ potassium phosphate buffer $\left(\mathrm{pH}\right.$ 7.4) containing $2 \mathrm{mM} \mathrm{MgCl}_{2}$ and complete protease inhibitor (see Recipes)

37. $0.6 \mathrm{M}$ sucrose solution (see Recipes)

38. $0.1 \mathrm{M}$ sodium citrate buffer ( $\mathrm{pH} 5$ ) containing $10 \%$ glycerol (see Recipes)

39. $2 \mathrm{mg}$ of rat liver cytosolic protein (see Recipes)

\section{Equipment}

1. $250 \mathrm{ml}$ bottle

2. $-80^{\circ} \mathrm{C}$ freezer

3. Sterile scissors and forceps

4. Variable volume pipettes (Tarsons, catalog numbers: 030050, 030040, 030020, 030000)

5. Incubator (Thermo Scientific)

6. Autoclave

7. Centrifuge (Thermo Scientific) 
8. Ultracentrifuge (Thermo Scientific, model: WXUltra90)

9. Laminar air flow (NEO Equipments, model: LX80)

10. Vortex (Tarsons, catalog number: 3020 )

11. $\mathrm{pH}$ meter (Sartorius, model: PB-11)

12. Magnetic stirrer (Tarsons, catalog number: 6030)

13. Spectrophotometer (Jasco, catalog number: V-630)

\section{Procedure}

A. Preparation of microsomal fraction containing HO-1 enzyme

1. Infect $80 \%$ confluent macrophage cells (RAW 264.7 or BMDM) in T25 flasks with Leishmania donovani promastigotes with a parasite to macrophage ratio (10:1) for the indicated time points $(0,0.25,0.5,1,2$ and $4 \mathrm{~h})$.

2. After incubation, discard the media and carefully wash the cells with $1 \mathrm{ml} \mathrm{PBS}$ solution and the steps were carried out by placing all the flasks on ice throughout.

3. Add $1 \mathrm{ml}$ potassium phosphate buffer to each of the flasks and gently scrape the cells using scrapers.

4. Transfer the scraped cells in a $50 \mathrm{ml}$ Falcon pre-chilled by placing on ice.

5. Add $2 \mathrm{ml}$ more potassium phosphate buffer.

6. Incubate the cells for 15 min on ice.

7. Briefly sonicate the cell suspensions at $80 \%$ amplitude for $15 \mathrm{~s}$ at $5 \mathrm{~min}$ interval for 3 times keeping on ice.

8. Add sucrose solution to the cell lysate to obtain the final concentration $0.25 \mathrm{M}$ sucrose.

9. Centrifuge the solutions at $1,000 \times g$ for $10 \mathrm{~min}$ at $4{ }^{\circ} \mathrm{C}$.

Note: The pellet will contain the nuclei.

10. Centrifuge the supernatant at $12,000 \times g$ for 15 min at $4{ }^{\circ} \mathrm{C}$.

Note: The pellet will contain the mitochondria.

11. Ultracentrifuge the supernatant at $105,000 \times g$ for $1 \mathrm{~h}$ at $4{ }^{\circ} \mathrm{C}$.

12. Discard the supernatant.

Note:The pellet is the microsomal fraction containing HO-1 enzyme.

13. Resuspend the pellet in $500 \mu \mathrm{l}$ of $0.1 \mathrm{M}$ potassium phosphate buffer.

14. Store at $-20^{\circ} \mathrm{C}$ until use.

B. Estimation of protein concentration (Bradford, 1976)

1. Prepare 6 dilutions of bovine serum albumin (BSA) $(10 \mathrm{mg} / \mathrm{ml})$ as standard with a range of 0 to $50 \mu \mathrm{g}$ protein in $995 \mu \mathrm{l}$ diluted Bradford assay reagent (1:5) in duplicate and adding $5 \mu \mathrm{l}$ from each of the test samples in $995 \mu$ l diluted Bradford assay reagent (1:5) in triplicate.

2. Mix all the samples by gently inverting 2 to 3 times.

3. Incubate all at room temperature for $5 \mathrm{~min}$ and read absorbance at $595 \mathrm{~nm}$. 
Note: Do not keep the prepared solutions for more than $1 \mathrm{~h}$ at room temperature.

C. Isolation of rat liver cytosolic fraction containing biliverdin reductase

1. Euthanize a Sprague Dawley rat.

2. Perfuse the liver with $0.9 \% \mathrm{NaCl}$ solution in situ via hepatic portal vein until fully blanched.

3. Excise out the blanched liver and mince it completely with help of scissors.

4. Homogenize the liver sample in $5 \mathrm{ml}$ of $0.1 \mathrm{M}$ sodium citrate buffer using tissuelyzer (Bio-Rad)

5. Centrifuge the homogenate at $10,000 \times g$ for $20 \mathrm{~min}$ at $4{ }^{\circ} \mathrm{C}$.

6. Carefully pipette out the supernatant and ultracentrifuge the sup at $105,000 \times g$ for $1 \mathrm{~h}$ at $4{ }^{\circ} \mathrm{C}$.

7. The supernatant serves as the source of biliverdin reductase.

8. A portion of the obtained supernatant was tested for biliverdin reductase activity by assessing the amount of bilirubin produced from biliverdin via measuring the absorbance at $464 \mathrm{~nm}$ (bilirubin) and $670 \mathrm{~nm}$ (biliverdin). Five $\mu \mathrm{g}$ of protein from the obtained supernatant was incubated with $10 \mu \mathrm{M}$ biliverdin (Sigma) and $400 \mu \mathrm{g} / \mathrm{ml}$ bovine serum albumin (BSA) in $100 \mathrm{mM}$ potassium phosphate buffer $(\mathrm{pH} 7.4)$ at $37^{\circ} \mathrm{C}$ for $5 \mathrm{~min}$ in a total volume of $200 \mu \mathrm{l}$. The reaction was initiated by addition of $1 \mathrm{mM} \mathrm{NADPH}$. The protein concentration of the supernatant was around $10 \mathrm{mg} / \mathrm{ml}$.

9. Store at $-80^{\circ} \mathrm{C}$ until use.

Note:Use the solution as early as possible as the enzymes lose their activity upon storage.

D. Assessment of heme oxygenase-1 activity

1. Incubate $600 \mu \mathrm{g}$ of microsomal protein with a reaction mixture containing $1 \mathrm{mM} \mathrm{NAD}(\mathrm{P}) \mathrm{H}$, $2 \mathrm{mM}$ glucose-6-phosphate, $1 \mathrm{U}$ glucose-6-phosphate dehydrogenase (Sigma-Aldrich), $25 \mu \mathrm{M}$ hemin, $2 \mathrm{mg}$ of rat liver cytosolic protein, and $100 \mathrm{mM}$ potassium phosphate buffer $(\mathrm{pH}$ 7.4).

2. Adjust the final volume to $400 \mu \mathrm{l}$ with potassium phosphate buffer $(\mathrm{pH} 7.4)$.

3. Place the tubes in the dark for $1 \mathrm{~h}$ at $37^{\circ} \mathrm{C}$.

4. After $1 \mathrm{~h}$, terminate the reaction by placing the tubes on ice for $2 \mathrm{~min}$.

5. Determine HO-1 activity by measuring bilirubin concentration by spectrophotometer.

E. Spectrophotometric detection of bilirubin

1. Determine bilirubin concentration by the difference in absorption between 464 and $530 \mathrm{~nm}$ (extinction coefficient, $40 \mathrm{mM}^{-1} \mathrm{~cm}^{-1}$ for $\mathrm{BL}$ ).

2. Express HO-1 activity in picomoles of $\mathrm{BL}$ formed per milligram microsomal protein per hour (Figure 2). 


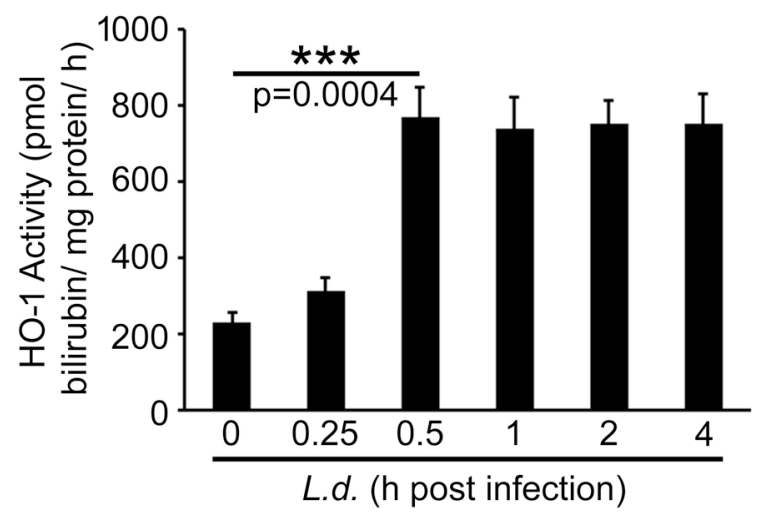

Figure 2. HO-1 activity was measured in Leishmania donovani infected RAW 264.7 macrophages for the indicated time periods $(0-4 \mathrm{~h})$

\section{Data analysis}

Calculate the difference between the two O.D.s.

$A=A_{464}-A_{530}$

Incubation was performed for $1 \mathrm{~h}$.

Therefore, $\triangle \mathrm{A}=\mathrm{A} \mathrm{h}^{-1}$

Path length $=1 \mathrm{~cm}$

Therefore, using Lambert Beers law $[A=\varepsilon \mathrm{Cl}]$;

Amount of $\mathrm{BL}=\mathrm{c}=\frac{\Delta \mathrm{A}}{(\varepsilon \times 1)}$ [where, $\mathrm{c}=$ concentration, $\varepsilon=$ extinction coefficient, $40 \mathrm{mM}^{-1} \mathrm{~cm}^{-1}$ for bilirubin $(B L), I=$ path length, $1 \mathrm{~cm}$ ]

$$
\begin{aligned}
& =\frac{\Delta \mathrm{A}}{(40 \times 1)} \mathrm{h}^{-1} /\left(\mathrm{mM}^{-1} \mathrm{~cm}^{-1} \times \mathrm{cm}\right) \\
& =\frac{\Delta \mathrm{A}}{40} \mathrm{~h}^{-1} / \mathrm{mM}^{-1} \\
& =\frac{\Delta \mathrm{A} \times 10^{3}}{40} \mathrm{pmol} \mu \mathrm{l}^{-1} \mathrm{~h}^{-1}\left[1 \mathrm{mM}=10^{3} \text { picomoles } \mu^{-1}\right]
\end{aligned}
$$

Total volume of reaction was $400 \mu \mathrm{l}$

Therefore, $\mathrm{c}=\frac{\Delta \mathrm{A} \times 10^{3} \times 400}{40} \mathrm{pmol} \mathrm{h}^{-1}$

$$
=\left(\Delta \mathrm{A} \times 10^{4}\right) \mathrm{pmol} \mathrm{h}^{-1}
$$

Amount of protein added was $600 \mu \mathrm{g}$.

Therefore, $c=\frac{\Delta \mathrm{A} \times 10^{4}}{600 \times 10^{-3}}$ pmoles of Billirubin (BL) $(\mathrm{mg} \text { protein })^{-1} \mathrm{~h}^{-1}$

$$
\left.=\frac{\Delta \mathrm{A} \times 10^{5}}{6} \text { pmoles of Billirubin (BL) (mg protein }\right)^{-1} \mathrm{~h}^{-1}
$$

\section{$\underline{\text { Recipes }}$}

1. Phosphate buffer saline/buffer $(\mathrm{pH} 7.4)$

a. Add $8 \mathrm{~g}$ of $\mathrm{NaCl}(\mathrm{M} . \mathrm{W} .=58.44 \mathrm{~g} / \mathrm{mol}$ ) in a sterilized $1 \mathrm{~L}$ bottle 
b. Add $1.44 \mathrm{~g}$ of $\mathrm{Na}_{2} \mathrm{HPO}_{4}$ (M.W. $\left.=141.96 \mathrm{~g} / \mathrm{mol}\right)$

c. $\quad$ Add $0.2 \mathrm{~g}$ of $\mathrm{KCl}(\mathrm{M} . \mathrm{W} .=74.55 \mathrm{~g} / \mathrm{mol})$

d. Add $0.24 \mathrm{~g}$ of $\mathrm{KH}_{2} \mathrm{PO}_{4}$ (M.W. $=136.08 \mathrm{~g} / \mathrm{mol}$ )

e. Dissolve the reagents completely in about $800 \mathrm{ml}$ sterilized distilled water $\left(\mathrm{dH}_{2} \mathrm{O}\right)$

f. Adjust the $\mathrm{pH}$ to 7.4 using $1 \mathrm{M} \mathrm{HCl}$ or $1 \mathrm{M} \mathrm{NaOH}$ (as required)

g. Make up the final volume to $1 \mathrm{~L}$ with sterilized distilled water

h. Sterilize the solution by autoclaving at $15 \mathrm{lbs}$ pressure $\left(121^{\circ} \mathrm{C}\right)$ for $15 \mathrm{~min}$

i. Store the solution at $4{ }^{\circ} \mathrm{C}$

2. $0.1 \mathrm{M}$ potassium phosphate buffer containing $2 \mathrm{mM} \mathrm{MgCl}_{2}$ and complete protease inhibitor ( $\mathrm{pH}$ 7.4)

a. Add $2.61 \mathrm{~g}$ of $\mathrm{KH}_{2} \mathrm{PO}_{4}$ (M.W. $=136.08 \mathrm{~g} / \mathrm{mol}$ ) in a sterilized $250 \mathrm{ml}$ bottle

b. Add $2.04 \mathrm{~g}$ of $\mathrm{K}_{2} \mathrm{HPO}_{4}(\mathrm{M} . \mathrm{W} .=174.18 \mathrm{~g} / \mathrm{mol}$ )

c. Add $28.56 \mathrm{mg}$ of $\mathrm{MgCl}_{2}$ (M.W. $=95.211 \mathrm{~g} / \mathrm{mol}$ )

d. Dissolve the reagents completely in about $120 \mathrm{ml}$ sterilized distilled water $\left(\mathrm{dH}_{2} \mathrm{O}\right)$

e. Adjust the $\mathrm{pH}$ to 7.4 using $1 \mathrm{M} \mathrm{HCl}$ or $1 \mathrm{M} \mathrm{NaOH}$ (as required)

f. Make up the final volume to $150 \mathrm{ml}$ with sterilized distilled water

g. Sterilize the solution by autoclaving as mentioned above

h. Store the solution at $4{ }^{\circ} \mathrm{C}$

On the day of the experiment aliquot of $25 \mathrm{ml}$ of the solution and add complete protease inhibitor just prior to use.

3. $0.6 \mathrm{M}$ sucrose solution

a. Add $20.53 \mathrm{~g}$ of sucrose (M.W. $=342.29 \mathrm{~g} / \mathrm{mol}$ ) to $80 \mathrm{ml}$ sterilized $\mathrm{dH}_{2} \mathrm{O}$ in a sterilized $250 \mathrm{ml}$ bottle

b. Dissolve the reagent completely

c. Make up the final volume to $100 \mathrm{ml}$ and sterilize by autoclaving as mentioned above

d. Store at $4{ }^{\circ} \mathrm{C}$

4. $0.1 \mathrm{M}$ sodium citrate buffer

a. Add $2.58 \mathrm{~g}$ of sodium citrate (M.W. $=258.06 \mathrm{~g} / \mathrm{mol}$ ) to $80 \mathrm{ml}$ sterilized $\mathrm{dH}_{2} \mathrm{O}$ in a sterilized $250 \mathrm{ml}$ bottle

b. Dissolve the reagent completely

c. Adjust the $\mathrm{pH}$ to 5.0 using $1 \mathrm{M} \mathrm{HCl}$ or $1 \mathrm{M} \mathrm{NaOH}$ (as required)

d. Add $10 \mathrm{ml}$ of glycerol solution

e. Make up the volume to $100 \mathrm{ml}$ and sterilize by autoclaving as mentioned above

f. Store at $4{ }^{\circ} \mathrm{C}$

5. Rat liver cytosol

a. Euthanize a Sprague Dawley rat

b. Perfuse the liver with $0.9 \% \mathrm{NaCl}$ solution in situ via hepatic portal vein until fully blanched (Wen et al., 2012)

c. Excise out the blanched liver and mince it completely with help of scissors 
d. Homogenize in $5 \mathrm{ml}$ of $0.1 \mathrm{M}$ sodium citrate buffer $\mathrm{pH} 5$ containing $10 \%$ glycerol

e. Centrifuge the obtained homogenate at $10,000 \times \mathrm{g}$ for $20 \mathrm{~min}$

f. Collect the resulting supernatant carefully and ultracentrifuge at $105,000 \times \mathrm{g}$ for $1 \mathrm{~h}$

g. Collect the obtained supernatant carefully and store in aliquots at $-80^{\circ} \mathrm{C}$ for use

Note:Use the prepared as early as possible as enzymes gradually loose their activity upon storage.

6. Bone marrow derived macrophages (BMDM)

a. Euthanize the mouse

b. Lay the mouse in a supine position and affix it by pinning the four legs through the mouse paw pads below the ankle joint

c. Thoroughly spray the mouse abdomen and hind legs with $70 \%$ ethanol

d. Make an incision at the top of each hind leg and pull the skin outwards exposing the muscle using sterile scissors and forceps

e. Use scissors to remove maximum muscles and connective tissues from the bones. Carefully isolate the entire femurs and tibia without cutting the bone ends or breaking the bones

f. Clean the bones from any attached tissues with help of tissue papers

g. Transfer the bones with help of forceps in a Petri dish containing $70 \%$ ethanol (EtOH) for one minute followed by air dry for about 5 min inside cell culture hood

h. Cut both ends of the isolated bones carefully so that the bones do not get shattered Notes:

i. Hold the femur or tibia with help of forceps. Place the scissors just above the joint to prevent the bone from shattering. Turn the bone and repeat the procedure.

ii. Do not let the cut ends of the bones touch anything as this leads to contamination of the marrow.

i. Flush out the bone marrow into a $50 \mathrm{ml}$ Falcon tube by inserting a 26-gauge needle attached to a $10 \mathrm{ml}$ syringe filled with 1x PBS (containing Antibiotic solution) at the knee side of both types of bone. Pass the PBS through the bone until the colour of the bone turns white from reddish, indicating that most of the marrow has been expelled

j. Discard the bone into an empty Petri dish Notes:

i. Perform these steps as early as possible for each bone IMMEDIATELY following the cutting of the bone.

ii. DO NOT put a bone down between cutting and flushing.

k. Centrifuge the collected cell suspension at $1,500 \mathrm{rpm}$ for $10 \mathrm{~min}$ at $4{ }^{\circ} \mathrm{C}$

I. Wash the cell pellet again with $1 \times$ PBS

$\mathrm{m}$. Resuspend the cells in RPMI 1640, supplemented with $100 \mathrm{U} / \mathrm{ml}$ penicillin and $100 \mu \mathrm{g} / \mathrm{ml}$ streptomycin, $10 \% \mathrm{FCS}$, and $25 \mathrm{ng} / \mathrm{ml}$ GM-CSF and were incubated at $5 \% \mathrm{CO}_{2}, 95 \%$ humidity, at $37^{\circ} \mathrm{C}$ 
$\mathrm{n}$. On the 4th day, the media will be discarded and add new media containing $100 \mathrm{U} / \mathrm{ml}$ penicillin and $100 \mu \mathrm{g} / \mathrm{ml}$ streptomycin, $10 \% \mathrm{FCS}$, and $25 \mathrm{ng} / \mathrm{ml} \mathrm{GM}-\mathrm{CSF}$

o. On Day 6, BMDM cells will be obtained for usage

\section{Acknowledgments}

This work was supported by Department of Biotechnology (BT/HRD/NBA/38/03/2018), Indo Israel Grant from the University Grants Commission [F. 6-10/2016(IC)], Department of Science and Technology (SB/SO/BB-0055/2013), Department of Biotechnology, West Bengal [221/BT(Estt)/RD-40/2014], and the University with Potential for Excellence II (Grant UGC/148/UPE/ST1). M.B. and S.S. received their fellowships from the University Grants Commission (New Delhi).The research was supported by Council of Scientific and Industrial Research, New Delhi, India.

\section{Competing interests}

The authors have no competing interests.

\section{Ethics}

Animal maintenance and the experiments were performed in accordance with the guidelines provided by the Committee for the Purpose of Control and Supervision of Experiments on Animals (New Delhi, India). The protocol was approved by the Institutional Animal Ethics Committee (IAEC) of Bose Institute (Kolkata, India) (IAEC approval no. IAEC/BI/82/2017).

\section{$\underline{\text { References }}$}

1. Bradford, M. M. (1976). A rapid and sensitive method for the quantitation of microgram quantities of protein utilizing the principle of protein-dye binding. Anal Biochem 72: 248-254.

2. Kathirvel, E., Chen, P., Morgan, K., French, S. W. and Morgan, T. R. (2010). Oxidative stress and regulation of anti-oxidant enzymes in cytochrome P4502E1 transgenic mouse model of non-alcoholic fatty liver. J Gastroenterol Hepatol 25(6): 1136-1143.

3. Kutty, R. K. and Maines, M. D. (1981). Purification and characterization of biliverdin reductase from rat liver. J Biol Chem 256(8): 3956-3962.

4. Lincoln, B. C., Mayer, A. and Bonkovsky, H. L. (1988). Microassay of heme oxygenase by high-performance liquid chromatography: application to assay of needle biopsies of human liver. Anal Biochem 170(2): 485-490.

5. Maines, M. (1996). Carbon monoxide and nitric oxide homology: differential modulation of heme oxygenases in brain and detection of protein and activity. Methods Enzymol 268: 
473-488.

6. Maines, M. D. and Kappas, A. (1974). Cobalt induction of hepatic heme oxygenase; with evidence that cytochrome P-450 is not essential for this enzyme activity. Proc Natl Acad Sci U $S$ A 71(11): 4293-4297.

7. Missall, T. A., Lodge, J. K. and McEwen, J. E. (2004). Mechanisms of resistance to oxidative and nitrosative stress: implications for fungal survival in mammalian hosts. Eukaryot Cell 3(4): 835-846.

8. Paiva, C. N. and Bozza, M. T. (2014). Are reactive oxygen species always detrimental to pathogens? Antioxid Redox Signal 20(6): 1000-1037.

9. Ryter, S., Kvam, E. and Tyrrell, R. M. (1999). Heme oxygenase activity determination by high-performance liquid chromatography. Methods Enzymol 300: 322-336.

10. Saha, S., Basu, M., Guin, S., Gupta, P., Mitterstiller, A. M., Weiss, G., Jana, K. and Ukil, A. (2019). Leishmania donovani Exploits Macrophage Heme Oxygenase-1 To Neutralize Oxidative Burst and TLR Signaling-Dependent Host Defense. J Immunol 202(3): 827-840.

11. Schacter, B. A. (1978). Assay of microsomal heme oxygenase in liver and spleen. Methods Enzymol 52: 367-372.

12. Sierra, E. E. and Nutter, L. M. (1992). A microassay for heme oxygenase activity using thin-layer chromatography. Anal Biochem 200(1): 27-30.

13. Tenhunen, R., Marver, H. S. and Schmid, R. (1969). Microsomal heme oxygenase. Characterization of the enzyme. J Biol Chem 244(23): 6388-6394.

14. Vreman, H. J. and Stevenson, D. K. (1988). Heme oxygenase activity as measured by carbon monoxide production. Anal Biochem 168(1): 31-38.

15. Wen, J. W., Olsen, A. L., Perepelyuk, M. and Wells, R. G. (2012). Isolation of rat portal

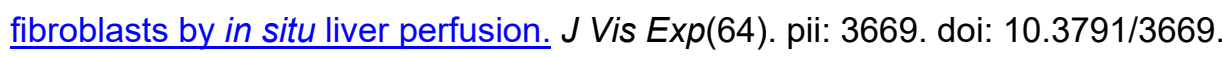

